\title{
Evaluating Co-Curricular Activities as Integral Component of the Human Life: Curriculum Implications for the Nigerian Context
}

\author{
Cecilia N. Onyekwena \\ Department of Physical and Health Education, \\ Federal College of Education (Technical) \\ Umunze-Anambra State,Nigeria
}

\section{Doi:10.5901/mjss.2013.v4n7p35}

\begin{abstract}
Co-curricular activities, also popularly known and called extr-curricular activities by renowned educationists like Bucher and Association (1974), Vannier and Fait (1975) named "Extra-Class Activities" may be regarded as those school activities that take place outside the official designated class-room hours or periods. Traditionally, the periods exclusively and officially designated schooling hours during which activities under reference take place are very early in the mornings prior to the commencement of classes at 8.00a.m as well as in the evenings shortly after afternoon studies at 5.00p.m respectively. Notably co-curricular or extra-class activities complement the courses of study normally scheduled within the overall school curriculum. This paper as it were intended to appraise Sports in the wider ramifications as integral component of the school curriculum that should be organized and implemented in a way that will approximate and extend the welfare of the average Nigerian society at large. The paper made an overview of types and/elements of sports as well as their relevance in the school curriculum paradigm. Recommendations included among others that the school curriculum should be reviewed regularly to justify the continued existence of some sporting activities with passage of time. Government at all levels, private initiatives and religious organizations having stake in the education enterprise as well as the well being of the youth and children should collaborate in developing school sports.
\end{abstract}

\section{Introduction}

Co-curricular activities are adjunctive or additive to the regular academic or class-room work and are specially arranged with the sole aim of enabling the students to have meaningful digression from academic monotony and boredom. Examples of the extra-class activities abound in drama, music, dancing, arts, crafts, gardening and above all sports.

At this juncture, it may be gratifying to note that the essence of the early morning physical fitness exercises is to enable the students supple their joints, activate their body systems as well as the various groups off muscles in order to tone them up into a state of physiological readiness to cope or brace up with the challenges of the day's academic load and other school routine work.

This is the very period during which every student within and outside the hotels a school is expected to participate very massively and actively in one form of sporting activity or the other as positive means of recreating themselves and forestalling drudgery.

\section{Classes of Sporting Activities}

Sporting as co-curricular or extra-class activities that could simply be defined as those physical activities that people indulge in either as individuals or as groups/teams for the purpose of achieving all-round body development and fitness (physical, mental, emotional, social as well as economic fitness). 
Distinctively, there are two main types of sports the recreational and the competitive sports. There is, however, no clear cut demarcation or hard and fast rule as to which ones are recreational or competitive in nature. It should be noteworthy that, at times, depending on the purpose or purposes in view and the individuals or groups concerned, sporting activities meant recreational purposes could also be utilized for competitive purposes too, and vice versa.

\section{Recreational Sports}

The recreational sports are those physical activities that are performed during one's leisure period that is, out of one's volition or choice, and not out of compulsion. The leisure time physical activities give those who participate in them enjoyment, satisfaction, happiness, refreshment, contentment, peace of mind as well as reinforcement of companionship, group identity, sense of belonging, esteem, actualization, mutual interest and concern for others.

\section{Competitive Sports}

The competitive sports, on the other hand, may be regarded as those physical activities which individuals or groups/teams indulge in with the sole aim of winning out the other individuals or teams/groups to emerge victorious and become the overall champion. Competitive sports have recorded history and tradition which stream physical exertion within prescribed rules and regulations. In competitive sports, the actors are individuals who represent formally organized pressure groups and who wish to achieve set objectives and goals or recognition by defeating the opponent or opportunities. These are therefore, characterized by rivalry between two individuals or among teams, competing to displace reach or one another of from winning some valued prizes or gifts such as honour, recognition, trophy or money (Onyekwena,2010).

In competitive sports, one team or individuals has to win or lose; a draw is usually regarded as an unfortunate outcome. Competitive sports require long periods of persistent, diligent, systematic and wellplanned practice and training sessions, apart from physical exertion, in order to properly simulate the participants to perfect the skills, techniques and strategies of the sports in question (Onyekwena, 2008).

It should be of interest to note that a participant in competitive sports cannot willingly quite the field of play, despite injury, fatigue and boredom. This is consequent upon the prestige at stake as well as other attendant benefits inherent in them.

Competitive sports may be categorized into six sub-areas, namely: Intra-mural or Inter-house sports, the Extra-Mural or Inter-school sports, the Inter-Scholastic sports, Inter-Collegiate sports, the Adapted or Sports for the Disabled and the last, but not the least, the Adult or Sports outside school sports.

\section{The Intra-mural Sports}

The Inter-mural sports competitions are synonymous with the popularly known Inter-house sports competitions. They are the sports competitions that take place within the four walls of a school and among the various dormitories or hostels or houses in a school. Those periods create ample opportunities for students to voluntarily participate in sporting activities such as Calisthenics, Karate or Man-O-War demonstration, Fashion Parade, particularly for the female students and such like things. The periods provide for a mutual interaction between the school authorities and the parents/guardians of the students who are usually invited to such occasions to come and joyfully see for themselves what else their children and wards are capable of doing, apart from academic work. The periods are fertile grounds or appropriate laboratory stages for testing practically what the students learnt during their basic instructional programme of physical education, affording students the opportunity for mass participation in sporting activities. The participants 
comprise young and the old, the small, and the big, the skilled and the unskilled, the sick and strong, the children of the rich and those of the poor alike.

It also involves both sexes, competing in sports separately and in co-educational programme. The Intra-mural or Inter-house sports competitions serve as appropriate avenues for hunting for hidden talents or potential athletes or players that will be groomed further to compete for the school in the Extra-mural or InterSchool Sports competitions.

\section{The Extra-mural Sports}

The Extra-mural sports competitions, otherwise, known as the Inter-School sports competitions are those that take place between the athletes or players of one college and those of another College. The students that partake of the Extra-mural sports competitions are selected during the Intra-mural or Inter-departmental sports competitions. They are further nurtured to properly condition them to the actual competitive stress expected in the Extra-mural sports. Consequently, the athletics and players involved here are, therefore, more skilled than those of the Intra-mural sports competitions. Extra-mural sports are in turn, further preparatory stage for competitors that later compete in the Inter-Scholastic sports competition.

\section{The Inter-Scholastic Sports}

The Inter-Scholastic sports competitions are the ones that take places among students-athletes and players within a designated locality may be, say within a state or nation. Examples of these sports are the zonal final of the Nigerian Association of colleges of Education Games (NACEGA), National Universities Games (NUGA), Nigerian Polytechnic Games (NIPOGA) competition etc. The competitors in these sports fiesta are much, much fewer in number than those of the previous two, that is, the Intra-mural and the Extra-mural sports competitions, respectively. Besides, these athletes and players that compete in the Inter-Scholastic sports competitions are the skilled, more experienced and more advanced than those of the previous two sports, respectively.

\section{The Inter-Collecgiate Sports}

The Inter- collegiate sports competitions are those sporting activities that are held among the Tertiary Institutions such as Nigeria Universities Games Associations (N.U.G.A.), the West African Universities Games (W.A.U.G.), the Nigeria Polytechnic Games Association (N.I.P.G.A.), just to name of them. The competitors here are highly advanced, highly experienced and highly skilled, since they had previously been involved in these sports in the post-primary schools.

It should be noted that the Inter-Scholastic and the Inter-collegial sports competitions are characterized by measurable publicity, commercialization, spectatorism, reward and moderate orientation towards winnings.

\section{The Adapted or Disabled Sports}

The Adapted or Disabled sports are synonymous with the Handicapped or sports for the A typical. These are the sports fashioned out for the handicapped individuals or persons with physical challenges in order to give then sense of belonging, identity, esteem and actualization as is the case with other fellow human beings. They are specialized forms of sports with special contrivances that enable the handicapped individuals to recreate and exercise themselves in varied physical activities of their choice, without much hindrance, just as the normal athletes and players would do. 


\section{Adult sports or outside school sports}

On the other hand, the last two of the six classes sports identified earlier namely the Adapted or the Disabled sports and the Adult or Sports Outside School sports come within the managerial jurisdiction of the National Sports Commission (N.S.C) and the States Ministries of Youth and Sports (States Sports Councils).

The sporting activities under reference consist of the Sports for the Disabled, the Challenge Football Cup Matches, the Professional League matches, the State and the National Sports Festivals, the Open and Classic Athletic Championships, Some of the Sports under this Associations jurisdiction include: Football, Handball, Basket ball, Volley ball, Hockey, Cricket, Chess, Boxing, Judo, Karate Taekwondo, Swimming and other sports Associations, the African Cup of Nations popularly known as the Unity Cup, the Olympic Games and the World Cup.

It should be noted that Adult or Sports outside school are characterized by considerable and excessive publicity, commercialization, spectatorism, rewards and above all professionalized orientation towards winning even at all costs and by all means - foul or fair.

From the fore-going submissions, it becomes crystal clear that both the State and Federal Ministries of Youth and Sports are quite cooperate and independent, but complementary sports bodies, that co-exist, collaborate, co-operate and function symbiotically for the progress, promotion and development of sports generally. None of these two is, therefore, superior or inferior to the other.

\section{Implications of Sports in Overall Development Of Children and Youth}

In this $21^{\text {st }}$ Century global society, industrialization, automation, population explosion, urbanization, economic recession, unemployment, retrenchment and retirement of workers in both public and private sectors of the economy have precipitated unprecedented "forced free time" on the majority of the citizenry. This situation has given vent to idleness and inactivity as well as sedentary life-styles that either directly or indirectly affect the human dynamic equilibrium (Ajala, 1989). The resultant effects of these notably are frustration, boredom, proneness to immorality, kidnapping, violence, crime and other concomitant unwholesome behaviours. All these have their social, emotional, mental, physical and organic strains and stresses as well as economic fallouts on our students and the entire citizenry alike, thereby making lives devoid of fun, enjoyment, recreation and relaxation.

The prevalent strain and stresses resulting from the prevalence of the problems under review coupled with the cosmetic, psychedelic and materialistic life-styles of our space-age, of which our students are part and parcel of has inadvertently given rise to the emergence of organic diseases, emotional and cardiac problems and other mal-functions of the body. Idleness and inactivity can predispose an individual to obesity, which is as much due to under or complete inactivity as to over-indulgence in eating and drinking. Insufficient or complete inactivity can also result to inefficient blood circulation, decreased production of white blood corpuscles (cells) which reduces body immunity or resistance to diseases.

- Idleness and inactivity can expose an individual to hypertension, heart-attack and stroke which are the major causes of death in our society today. Inactivity can result to a drastic reduction in the strength, size and tone of the muscles and invariably to atrophy.

- Besides these, some individuals develop protruding stomach due to overindulgence in eating, drinking, idleness and inactivity. Weak, flabby abdominal muscles are known to be one of the major causes of low back pains. These weak muscles need to be strengthened and toned up to the normal level of turgidity through prescribed exercise regimen.

- Experience over the years has shown that due to common misconception that girls and ladies will develop thick musculature and invariably lose their elegance, sensational body contours and configurations as well as power of procreation by participating in sporting activities, most of them have, in consequence, abstained from indulging in sports and other life-saving physical activities, 
Ikeonu, (2000) and Uzoalor (1993). Apart from the above-mentioned problem, idleness and inactivity can generate problem of social isolationism and bottled up emotions. It is pertinent to note that emotional problems, when not put in check, metamorphose ultimately into more serious health challenges mental illness called psychosis (Onyekwena 2012).

\section{Recommendations with Curriculum Implications}

Because sporting activities are sine qua non to the lives of students in particular and the nation's citizens in general, it is, therefore, pertinent and appropriate to recommend as follows:

1. The State Government should allocate adequate funds to State Education Commission for running sports in schools as sports are capital intensive ventures within the school curriculum.

2. School authorities, parents, and guardians should encourage their students, children and wards massively to be active participants in sporting activities at school.

3. The government should endeavor to employ and post more Health and Physical Education Specialists to schools in order to ensure that each school has, at least, two Sports specialists to take care of the sports lives of the students for all-round education, body fitness and development.

4. The Federal, State and Local Governments should join hands together to provide adequate sports facilities and equipment in all primary, secondary and tertiary institutions in this country.

5. Business organizations and industrialists should be urged and encouraged to go into extensive production and manufacture of sports wears and equipment to reduce the prohibitive costs of sports materials in this country. This will go a long way to enhancing quantum active participation of students and the entire citizenry in sporting activities.

6. Communities should team-up with the Local and State Government to provide recreational facilities at village squares and at sites of available natural resources such as lakes, caves, rivers, hills and so forth in order to boost recreation and tourism in this state.

7. Curriculum and academic programmes have to be planned in such a way that would accommodate sports on the wider spectrum

\section{Conclusion}

I optimistically hope that if these recommendations are meticulously and carefully considered and religiously implemented, serious efforts should have been made towards totally eliminating or drastically reducing the organic, physical, mental, emotional, social and economic woes and problems of our students in particular and our entire citizenry in general. Finally, educational institution should therefore be oriented towards ensuring effective accommodation of sports in the curriculum with special reference to timing and organization.

\section{References}

Abone O.M, (2003), Marketing and Sponsorship of Sports in Nigerian Schools, ANJOPHER SD $\underline{1}$, (1).

Adedeji J.A, (1985), The Teaching of Physical \& Health Education. Ibadan ;West Books Publishers Ltd.

Ajala (1989), Physical Education for Secondary Schools, Ibadan; Macmillan, Nigeria Publishers Ltd.

Mbioya Ikhioya, (2001), O.S.A Empowering Sports Administrators for Effective Performance, Unpublished Seminar Paper.

Onyekwena C.N (2012), Evaluating the continued relevance of age-long traditional sporting activities in the school paradigm at the Basic Education Level. Paper presented at the Annual National conference of the School of Education, Alvan Ikoku Federal College of Education, Owerri $5^{\text {th }}-8^{\text {th }}$ November.

Onyekwena C.N (2011), Improving Youth productivity and social well-being through competitive sports. Invited paper p[resented at Career Day Celebration of The Seat of Wisdom Group of Schools, Nnewi gth July. 
Onyekwena C.N, (2008), Principles \& Practice of Physical Education \& Sports, Onitsha, AUB Prints

Uever, J.N. (2003), Risk Management Strategies for Effective Implementation of Quality UBE Physical Education and Sports Programmes, ANJOPHER, SD $\underline{1},(1$.

Uzoalor, (1993), Physical \& Health Education for Schools, Onitsha,;Diamond (JMB) Publishers. 


\title{
Political Violence and Socio-Economic Development in Nigeria
}

\author{
Denen, Grace Mbaveren \\ Department of Sociology \\ Plateau State University, \\ Bokkos-Nigeria
}

\section{Doi:10.5901/mjss.2013.v4n7p41}

\section{Abstract}

This paper has established impacts of violence on socio-economic development in Nigeria, and recommended the way forward.

\section{Introduction}

Violence has occurred so often in Nigeria, and elsewhere, that it is considered 'normal', except when there is a major loss of lives and property-as those instances in Syria, Egypt, Israel-Pakistan, America (Sept $11^{\text {th }}$ 2001), DR, or Congo, Nigeria (Niger delta, Borno, Yobe Plateau, Bauchi). "Charred remains of buildings, commercial centres, as well as hulks of cars, trucks serve as mute testimonies of violence" (Adrian, 2011, Alubo, 2011). The main objective of this paper is to examine the likely causes of political violence, and their negative effects on the socio-economic development of the people in Nigeria.

\section{Political Violence}

Political violence is the use of destructive means or methods in an unlawful manner against persons, property, institutions, in order to publicise grievances, coerce or intimidate a government, opponents, the civilian population, in furtherance of political, socio-economic, religious objectives. It is terror and destruction that is systematically, planned and executed, to achieve political goals. The targets often include; Government functionaries and institutions, identified individuals or groups, innocent public-bystanders, traders, and so on (http://legal-dictionary-thefreedictionary.com/political-violence).

Howell (2004) sees political violence as synonymous with 'thuggery' activities and means 'brutal' acts or behaviour by ruffians. To him, politics is the tireless repetition of misleading facts designed to depict an opponent as personally despicable, and in regard to governance, as dangerous to physical and spiritual life of a persons or nation. Violence involves acts characterized by rudeness, hooliganism, touting, intimidation and harassment. It involves behaviour that contradicts peace, harmony, interdependence among groups of people.

Political violence is an illegitimate and destructive means of seeking political power with a view to subverting popular opinion for parochial ends through self imposition. Therefore, political violence is simply the "criminalization of politics, to scare off the 'good' people, leaving politics in the hands of ruffians, thugs, hooligans, touts", etc. Violence in politics is the entrenchment of the hijack syndrome, of the right of the people to participate in the decision making process of matters that concern their welfare and development. Karl Schmit (In Schaefer, 2011) is of the view that, political violence, and violence generally is a disturbance to political equilibrium. Gur, (in NEPAD, 2003), sees political violence as collective attacks within a political community against the political regime, its actors-including competing political groups, as well as incumbent or its policies. 